\title{
Diagnosis of central nervous system infection by CSF sampling of the myelo- meningocele sac as an alternative to ventricular tap
}

\author{
M. Kaplan; N. Ucler; F. Bayrakli*; B. Duz** and F.S. Erol
}

Firat University, Department of Neurosurgery, Elazig. *Acibadem Maslak Hospital, Department of Neurosurgery, Istanbul. **Gulhane Military Medicine Academy, Department of Neurosurgery, Ankara. Turkiye.

\section{Summary}

Background. Infection significantly affects mortality and morbidity in myelomeningocele cases. Ventricular tap is the most common method performed to diagnose central nervous system (CNS) infection in myelomeningocele patients. However, the ventricular tap can cause serious trauma to the baby and to the family. Here we discuss the technique of taking a cerebrospinal fluid (CSF) sample from the sac in myelomeningocele cases.

Methods. The study comprised 24 myelomeningocele patients undergoing sac repair; 7 patients in the early period and 17 in the late period (after the first 24 hours). CSF samples were taken from the sac and via ventricular tap. In all patients' samples, cell count and cultures were compared.

Results. In patients who underwent early meningomyelocele repair there was no significant difference between sac and ventricular CSF. There were also no positive cultures in samples taken from both areas. In comparison, in the group submitted to late repair, the number of cells in the sac and ventricle CSF samples was over 10 in 4 of the 17 patients. The cultures from CSF samples taken from both areas were positive for $E$. coli. In 13 of 17 patients who were admitted to our clinic for late repair, there was no significant difference between the number of cells in the sac and in ventricular samples. Cultures taken from these patients were negative.

Conclusion. Puncture of the sac represents a quicker and more convenient way to obtain CSF in myelomeningocele cases. In addition, there was no increase in pain to a level that would cause stress for the baby. A CSF sample can be taken from the sac for diagnosis of CNS infection in myelomeningocele patients. This method, therefore, represents a safer and more comfortable option for both the patient and doctor.

KEY WORDS: CNS infection. Cerebrospinal fluid. Mye- lomeningocele. Ventricular tap.

Diagnóstico de infección del SNC mediante estudio del LCR del saco del mielomeningocele como alternativa a la punción ventricular

Resumen

Fundamentos. La infección de LCR afecta significativamente la mortalidad y morbilidad en pacientes con mielomeningocele. La punción ventricular es la técnica más frecuentemente utilizada para detectar infección del SNC en los casos de mielomeningocele. Sin embargo, la punción ventricular puede causar un grave estrés tanto para el niño como para la familia. En nuestro estudio, presentamos la técnica y resultados del examen de LCR obtenido a partir del saco del mielomeningocele.

Pacientes y métodos. El estudio comprende 24 pacientes con mielomeningocele sometidos a cierre quirúrgico de la malformación, 7 pacientes con reparación precoz y 17 con cirugía tardía (después de las primeras 24 horas). Las muestras de LCR fueron obtenidas del saco de la malformación y de los ventrículos mediante punción ventricular. Se compararon los resultados del recuento de células y los cultivos realizados a todos los pacientes.

Resultados. En los pacientes operados precozmente, no se encontraron diferencias significativas entre el LCR lumbar y ventricular. Tampoco se obtuvieron cultivos positivos en las muestras tomadas de ambas áreas. En los operados después de las primeras 24 horas, el recuento de células del LCR del saco y del ventrículo fue alrededor de 10 en 4 de los 17 pacientes. Se obtuvieron cultivos positivos $(E$. coli) de las muestras de LCR tomadas de ambas áreas. En 13 de 17 pacientes que fueron admitidos a nuestra clínica para reparación tardía, no hubo una diferencia significativa entre el número de células del saco y del LCR ventricular. Los cultivos de LCR obtenidos en estos pacientes fueron

Abreviaturas. CNS: central nervous system. CSF: cerebrospinal fluid

Recibido: 24-03-09. Aceptado:14-03-10 


\begin{abstract}
negativos.
Conclusión. Las muestras obtenidas a partir del saco del mielomeningocele representan un método más rápido y conveniente para obtener LCR en casos de mielomeningocele. Además, la punción no ocasiona aumento de dolor a un nivel que pueda causar estrés para el niño. Las muestras de LCR pueden ser obtenidas del saco de la malformación para el diagnóstico de infección del SNC en casos de mielomeningocele. Este método por consiguiente representa una opción segura y confortable para el paciente y el médico.
\end{abstract}

Diagnosis of central nervous system infection by CSF sampling of the myelomeningocele sac as an alternative to ventricular tap

PALABRAS CLAVE: Infección del SNC. Líquido cefalorraquídeo. Mielomeningocele. Punción ventricular.

\section{Introduction}

The risk for central nervous system (CNS) infection is high in myelomeningocele cases and this risk increases following the first 3 days. The other complication that can accompany these cases is hydrocephalus, a condition that often requires shunt treatment ${ }^{1-3}$. This situation increases the importance of the follow-up of myelomeningocele cases in search of the risk of infection ${ }^{4,5}$. Generally, a lumbar puncture is performed in cases of CNS infection to obtain a CSF sample. Ventricular tap is the preferred approach in open spinal dysraphism cases due to co-existing anatomical malformations, particularly in the sac. Another reason is the concern that sac and intracranial CSF samples may differ in composition. The reasons stated above have prompted this study to assess the feasibility of taking a CSF sample from the sac in myelomeningocele cases. We think that our study will be of help both to neurosurgeons as well as to paediatricians.

\section{Material and methods}

Twenty four myelomeningocele patients being treated in our clinic were recruited for the study and were assessed (table 1). Meningomyelocele repair was made in the early period (in the first 24 hours) in 7 patients and in the late period (after the first 24 hours) in the remaining 17 patients. CSF samples were taken immediately before the operation from patients undergoing sac repair in the early period. These patients had neither clinical nor laboratory infection parameters before operation (leukocyte count, sedimentation rate, ASO, C-reactive protein (CRP) levels were normal and they did not have fever). Sac and ventricular CSF samples were taken immediately after sac repair from the patients admitted to our clinic for late repair (after the first 24 hours). They also lacked infection parameters $(n=13)$. Within the late patient group, those with elevated temperature, leukocyte number, sedimentation rate, ASO, and CRP values, had CSF samples $(n=4)$ taken from the sac and via ventricular tap after admission to the clinic. CSF samples were analysed microscopically and cultures were taken. CSF sampling from both the sac and ventricle was repeated periodically during the treatment. Two parameters, cell count and culture (aerobe and anaerobe) were assessed in CSF samples taken from all the patients and both methods were compared. The CSF puncture was made only once in the patients with no infection's findings. During the treatment period, the punctures were repeated, at one-week intervals, in patients with infection's findings (once in 1 case, twice in 2 cases, three times in 1 case).

\section{CSF sampling from the sac}

The sac area was cleaned using saline followed by application of a iodine solution. The sac's neural plaque, membrane cover and adjacent skin tissue were determined anatomically. From the skin in the immediate vicinity of the membrane area, $2 \mathrm{cc}$ of CSF were aspirated with a needle by entering the sac at approximately a 30 degree angle. After the process procedure, the area was wiped with iodine and covered with a sterile sponge. No spontaneous CSF fistula was observed following the process.

\section{Results}

In the patients with early meningomyelocele repair, the CSF cell count before sac repair was below 10 and ventriculoperitoneal shunting was performed in the same session. The number of cells in ventricular CSF samples taken while placing the ventricular catheter was also below 10. There was no positive culture in the CSF samples taken from both areas in these patients.

Laboratory findings in 4 of the patients admitted to our clinic for late surgery indicated infection. In these patients the number of cells determined by microscopic analysis of the sac and ventricle CSF was above 10, and culture was positive (E. coli) from the CSF samples taken from both areas. In the diagnosis of CNS infection, there was consistency in CSF samples from both areas, with similar findings in both areas. There was no significant difference between the sac and ventricular CSF cell count from 13 patients that were admitted to our clinic in the late period with no infection and cell count below 10 . There was no positive culture from any of these patients (table 1).

\section{Discussion}

The complication of infection is frequently faced in myelomeningocele cases, particularly in those requiring shunting for hydrocephalus, where infection significantly affects the mortality and morbidity ${ }^{1,2,4}$. For this reason, 
Table 1

\begin{tabular}{|c|c|c|c|c|c|c|}
\hline Case/Sex & $\begin{array}{l}\text { Treatment } \\
\text { time } \\
\text { Early/late }\end{array}$ & $\begin{array}{l}\text { Markers } \\
\text { of infection } \\
+/ \text { - }\end{array}$ & $\begin{array}{l}\text { Sac CSF } \\
\text { count } \\
(\mathrm{H} / \mathrm{N})\end{array}$ & $\begin{array}{l}\text { Ventriculer } \\
\text { CSF count } \\
(\mathrm{TAP})(\mathrm{H} / \mathrm{N})\end{array}$ & $\begin{array}{c}\text { SAC CSF } \\
\text { Culture }\end{array}$ & $\begin{array}{l}\text { TAP CSF } \\
\text { Culture }\end{array}$ \\
\hline $1 / \mathrm{M}$ & Early & - & $\mathrm{N}$ & $\mathrm{N}$ & Negative & Negative \\
\hline $2 / \mathrm{M}$ & Early & - & $\mathrm{N}$ & $\mathrm{N}$ & Negative & Negative \\
\hline $3 / \mathrm{M}$ & Early & - & $\mathrm{N}$ & $\mathrm{N}$ & Negative & Negative \\
\hline $4 / \mathrm{M}$ & Early & - & $\mathrm{N}$ & $\mathrm{N}$ & Negative & Negative \\
\hline $5 / \mathrm{F}$ & Early & - & $\mathrm{N}$ & $\mathrm{N}$ & Negative & Negative \\
\hline $6 / F$ & Early & - & $\mathrm{N}$ & $\mathrm{N}$ & Negative & Negative \\
\hline $7 / F$ & Early & - & $\mathrm{N}$ & $\mathrm{N}$ & Negative & Negative \\
\hline $8 / \mathrm{F}$ & Late & - & $\mathrm{N}$ & $\mathrm{N}$ & Negative & Negative \\
\hline $9 / \mathrm{F}$ & Late & - & $\mathrm{N}$ & $\mathrm{N}$ & Negative & Negative \\
\hline $10 / \mathrm{M}$ & Late & - & $\mathrm{N}$ & $\mathrm{N}$ & Negative & Negative \\
\hline $11 / \mathrm{M}$ & Late & - & $\mathrm{N}$ & $\mathrm{N}$ & Negative & Negative \\
\hline $12 / \mathrm{M}$ & Late & - & $\mathrm{N}$ & $\mathrm{N}$ & Negative & Negative \\
\hline $13 / \mathrm{F}$ & Late & - & $\mathrm{N}$ & $\mathrm{N}$ & Negative & Negative \\
\hline $14 / \mathrm{F}$ & Late & - & $\mathrm{N}$ & $\mathrm{N}$ & Negative & Negative \\
\hline $15 / \mathrm{F}$ & Late & - & $\mathrm{N}$ & $\mathrm{N}$ & Negative & Negative \\
\hline $16 / F$ & Late & - & $\mathrm{N}$ & $\mathrm{N}$ & Negative & Negative \\
\hline $17 / \mathrm{M}$ & Late & - & $\mathrm{N}$ & $\mathrm{N}$ & Negative & Negative \\
\hline $18 / \mathrm{M}$ & Late & - & $\mathrm{N}$ & $\mathrm{N}$ & Negative & Negative \\
\hline 19/M & Late & - & $\mathrm{N}$ & $\mathrm{N}$ & Negative & Negative \\
\hline $20 / \mathrm{M}$ & Late & - & $\mathrm{N}$ & $\mathrm{N}$ & Negative & Negative \\
\hline $21 / \mathrm{F}$ & Late & + & $\mathrm{H}$ & $\mathrm{H}$ & E. Coli & E. Coli \\
\hline $22 / \mathrm{F}$ & Late & + & $\mathrm{H}$ & $\mathrm{H}$ & E. Coli & E. Coli \\
\hline $23 / \mathrm{F}$ & Late & + & $\mathrm{H}$ & $\mathrm{H}$ & E. Coli & E. Coli \\
\hline $24 / \mathrm{M}$ & Late & + & $\mathrm{H}$ & $\mathrm{H}$ & E. Coli & E. Coli \\
\hline
\end{tabular}

Distribution of all cases according to sex, treatment time (early /late), markers of infection (increased white blood cell, increased sedimentation rate, increased ASO and CRP, high fever.), CSF count of myelomeningocele SAC, CSF count of ventricular TAP, Culture of SAC CSF sample and culture of TAP CSF sample. M: Male, F: Female. H: CSF leukocyte count is more than 10. N: CSF leukocyte count is less than 10 .

diagnosis of CNS infection in these cases is more significant. Analysis of CSF samples is considered the gold standard for the diagnosis of CNS infection. Generally, a lumbar puncture is performed to obtain CSF samples from these patients. However, lumbar area anatomy changes and the presence of the myelomeningocele may cause difficulty for performing this diagnostic technique. Generally, lumbar puncture is not preferred due to concerns about causing damage and added technical difficulty. Ventricular tap has therefore been most commonly performed for this purpose. Intracranial bleeding and the risk of microorganism contamination of the CNS are the most serious complications that may arise. Although the introduction of microorganisms is also a risk of lumbar puncture, this procedure has the added concern of causing serious stress for the baby and the family. Repetition of puncture during treatment only increases this stress. The sac that exists in myelomeningocele represents an anatomically shorter way to gain 
CSF. Also, the area for obtaining the CSF is readily visible. There is no indication that pain perception is increased to a level that will cause stress for the baby. This may be due to the fact that this tissue is not completely mature in terms of sensory perception. Furthermore, performing the aspiration on the skin tissue of the sac close to the membrane area also prevents the formation of a CSF fistula after aspiration.

Although CSF in the bag is related to the spinal fluid, there is the question whether ventricular and sac CSF are different. The fact that the sac's fluid is composed of many compartments and sometimes the CSF's is dirtier in colour, constitutes a further evidence for this contention. In our patients, there was no difference between sac and ventricular CSF samples in terms of cell count. In infected patients, the sac CSF cell number was high and we observed that the ventricular CSF cell number increased at a similar rate in these patients. Similarly, there was no significant difference between the sac and ventricular CSF number of cells in non-infected patients.

Ventricular and sac CSF samples were analyzed for control purposes during the treatment of infection. In conjunction with the response to the treatment, it was observed that the number of cells in sac and ventricular CSF decreased similarly. In the CSF culture samples taken from both areas, the same microorganism was detected (E.coli) in patients with infection. There was no positive culture in the patients whose sac and ventricular CSF cell counts were normal.

Our results contribute to clinical practice in two aspects. First, when sac repair has not yet been performed, a CSF sample can be easily taken for diagnosis in myelomeningocele cases when CNS infection is suspected, and this method represents a safer and more comfortable option than ventricular puncture for both patient and doctor. Moreover, it will prevent the stress of taking CSF samples for control purposes during treatment. Secondly, obtaining a cell count by taking CSF sample from the sac before the operation shall expand the security margin for shunt infection in cases that have no infection findings and for which synchronous shunting in planned for treatment of hydrocephalus.

\section{References}

1. Heimburger, RF.: Early repair of myelomeningocele (spina bifida cystica). J Neurosurg 1972; 37: 594-600.

2. Machado, HR., Oliveira, RS.: Simultaneous repair of myelomeningocele and shunt insertion. Childs Nerv Syst 2004; 20: 107-109.

3. Mirzai, H., Ersahin, Y., Mutluer, S., Kayahan, A.: Outcme of patients with meningomyelocele. The Ege University experience. Childs Nerv Syst 1998; 14: 120-123.

4. Oktem, I.S., Menku, A., Ozdemir, A.: When should ventriculoperitoneal shunt placement be performed in cases with myelomeningocele and hydrocephalus. Turkish Neurosurgery $2008 ; 18: 387-391$.

5. Radmanesh, F., Nejat, F., El Khashab, M., Ghodsi, S.M., Ardebili, H.E.: Shunt complications in children with myelemeningocele: effect of timing of shunt placement. Clinical article. J Neurosurg Pediatr 2009; 3: 516-520.

Kaplan, M.; Ucler, N.; Bayrakli, F.; Duz, B.; Erol, F.S.: Diagnosis of central nervous system infection by CSF sampling of the myelomeningocele sac as an alternative to ventricular tap. Neurocirugía 2010; 21: 228-231.

Corresponding autor: Metin KAPLAN, M.D., Firat Universitesi, Tip Fakultesi, Norosirurji AD, Firat Tip Merkezi,

23200, Elazig, Turkiye.

E-mail: mtkaplan02@yahoo.com.tr 